\begin{tabular}{ll}
\hline \hline MINING AND METALLURGY INSTITUTE BOR & ISSN: 2334-8836 (Štampano izdanje) \\
UDK: 622 & ISSN: 2406-1395 (Online) \\
\hline \hline
\end{tabular}

UDK: $622.33 / .016(045)=111$

doi:10.5937/mmeb1802049D

Duško Đukanović, ${ }^{*}$ Vladimir Todorovic ${ }^{* *}$, Dejan Dramlic ${ }^{* * *}$, Jelena Trivan $^{* * * *}$

\title{
METHODOLOGICAL PROCEDURE FOR SELECTION THE TYPE AND CONSTRUCTION OF SELF-PROPELLED HYDRAULIC SUPPORT FOR COAL EXCAVATION ON THE EXAMPLE OF THE COAL DEPOSIT "POLJANA"
}

\begin{abstract}
For the application of a wide forehead method, decisive is an assessment, respectively, selection of the type and construction of self-propelled hydraulic support, both for horizontal and vertical excavation concentrations. This is especially important in the excavation of coal seams whose immediate floor and roof are composed of clay sediment.

In the last decades, this theme has not been more fully explored in the coal mines in Serbia, and its processing has the character of original research, whose aim is, with the obtained research results, to contribute to the development of mining science.

The coal deposit "Poljana", with a comprehensive expert analysis, was assessed as promising for activation in the production sense, especially taking into account the certified reserves of quality coal and natural-geological conditions favorable for the use of mechanized wide forehead excavation systems.

It is particularly important that the research is related to concrete the working conditions, with a particular emphasis on the geo-mechanical aspect and its connection with selection the type and construction of the self-propelled hydraulic support.

Keywords: mine, coal, support, coal excavation, wide forehead, coal deposit
\end{abstract}

\section{INTRODUCTION}

For the underground coal excavation in developed mining countries, in general, the methods of mechanized wide forehead excavation on the principle of horizontal or vertical concentration are applied, with a tendency of gradual to complete automation of the basic work operations.

In the entire production system of the pit, the basic and starting problem is the excavation, as the basic production unit, because other technological phases directly depend on it.

In essence, the methods of excavation of the coal seams are grouped according to their characteristic of the process of coal production into:

1. wide forehead excavation method;

2. chamber method of excavation;

3. pillar method of excavation.

\footnotetext{
*University of Belgrade, Technical Faculty Bor, Vojske Jugoslavije 12, e-mail: dusko585@ gmail.com ** JP za PEU, Uprava, Resavica, Petra Žalca 2, e-mail: vladimirtodorovic@live.com.au

**** Institute IMS, Belgrade, Bulevar Vojvode Mišića 43, e-mail: dejan.dramlic@institutims.rs

${ }^{* * * * *}$ University of Banja Luka, Faculty of Mining Prijedor, e-mail: jelena.trivan@ @r.unibl.org
} 


\section{DESCRIPTION THE \\ METHODOLOGY OF SELECTION \\ THE TYPE AND CONSTRUCTION \\ OF SELF - PROPELLED \\ HYDRAULIC SUPPORT}

By the wide-forehead methods, the horizontal and slightly inclined seams of coal, small, medium and large thickness can be successfully excavated as well as the steep seams with special solutions. The defining condition for applying the wide-forehead method in a particular deposit is the rational length of the excavation field (belt).

By definition, a wide-forehead excavation, supported with the self-propelled hydraulic support and supplied with the receiing machine as well as equipment for loading and transportation of coal, is considered to be as the mechanized excavation.

The self-propelled hydraulic support is more expensive than a single support. It is a complex, mobile machine with mechanical, hydraulic, electrical and electronic elements, which in continuous operation must withstand the load of rock mass, not to break and deform, to provide the working space and ensure the accelerated coal excavation [1]. The efficiency of use the self-propelled hydraulic support and entire mechanized complex of wide-forehead excavation is dependent on the adaptability of structure to the natural-geological conditions of exploitation, that is, the excavation $[2,3]$.

In the mines, the problem of securing and supporting the working area of excavation is extremely complex, so the area of underground coal excavation is determined for this research subject by the mechanized wide-foreheads, and $f$ narrower area of the coal deposit "Poljana", in order to demonstrate the methodological procedure for selecting the type and construction of the selfpropelled hydraulic supports as an integral part of the mechanized complex.
The natural and geological conditions in the coal deposit decisively influence the selection of the excavation system (methods and technology) and its technical - technological, economic and safety parameters $[4,5]$.

For the rational and efficient excavation of coal by the underground system, the conditions of the working environment, that is, the natural and geological conditions of the deposit must be studied in detail, and on the basis of the determined results, the excavation system and the associated mechanization shall be selected $[6,7]$.

Since the natural-geological conditions cannot be directly influenced, the technical and technological conditions of the excavation process must be adaptive with them. Adequately to conditions, chosen excavation method and excavation technology, the best construction of the machines for obtaining and transport, the choice of type and ways of supporting and managing the roof, as well as the organization of work, represent a number of possibilities for improving the effects of the excavation $[1,8,9]$.

The systematized natural-geological conditions that have a definite influence on the selection of the excavation system in specific coal deposits are shown in Table 1. [10].

Further consideration of the subject matter is continued by determining the ranking of influence the natural-geological conditions on the selection of the excavation system (Table 2) for specific conditions. [10].

Continuation of research in this topic is the definition of technological phases for the selected excavation system, through technical conditions (Table 3 ). 
The self-propelled hydraulic support is a special type of equipment used to secure and support the working front of a wideforehead, and it is functionally linked to the machine for coal obtaining and coal transport devices. In mining practice, there are several types of self-propelled hydraulic supports, as supporting (syllable), supportshield (syllable-shield) and shield. Supporting platforms are used in the supporting of a wide-forehead work area for larger roof ranges (over $4 \mathrm{~m}$ ), while support-shield supports are designed to maintain a working space with a span of 3-4 m. Shield supports are designed to support the work space of a wide-forehead with a small span of immediate roof of 2-3,5 m. In relation to the possibility of supporting the workspace, depending on the type of roof, the support is selected according to the security parameters that characterize that sort and type of self-propelled hydraulic support. The selected self-propelled hydraulic support must satisfy, on the first place, the requirements related to the required load capacity, assessed by the interaction between the self-propelled hydraulic supports and massive [11].

In mining practice, there are several approaches for solving the problem of selection the required load capacity of self - propelled hydraulic support. According to the first approach, the type of support is selected, whose reaction will prevent excessive convergence, and, on the other hand, the other approach starts from the point of view of selection the type of selfpropelled hydraulic support with the largest reaction, thus preventing separation of the seams in the forehead area. In this second approach, the specific pressure occurs as a limiting factor on both roof and floor, which must not exceed the hardness of immediate roof or floor [12].

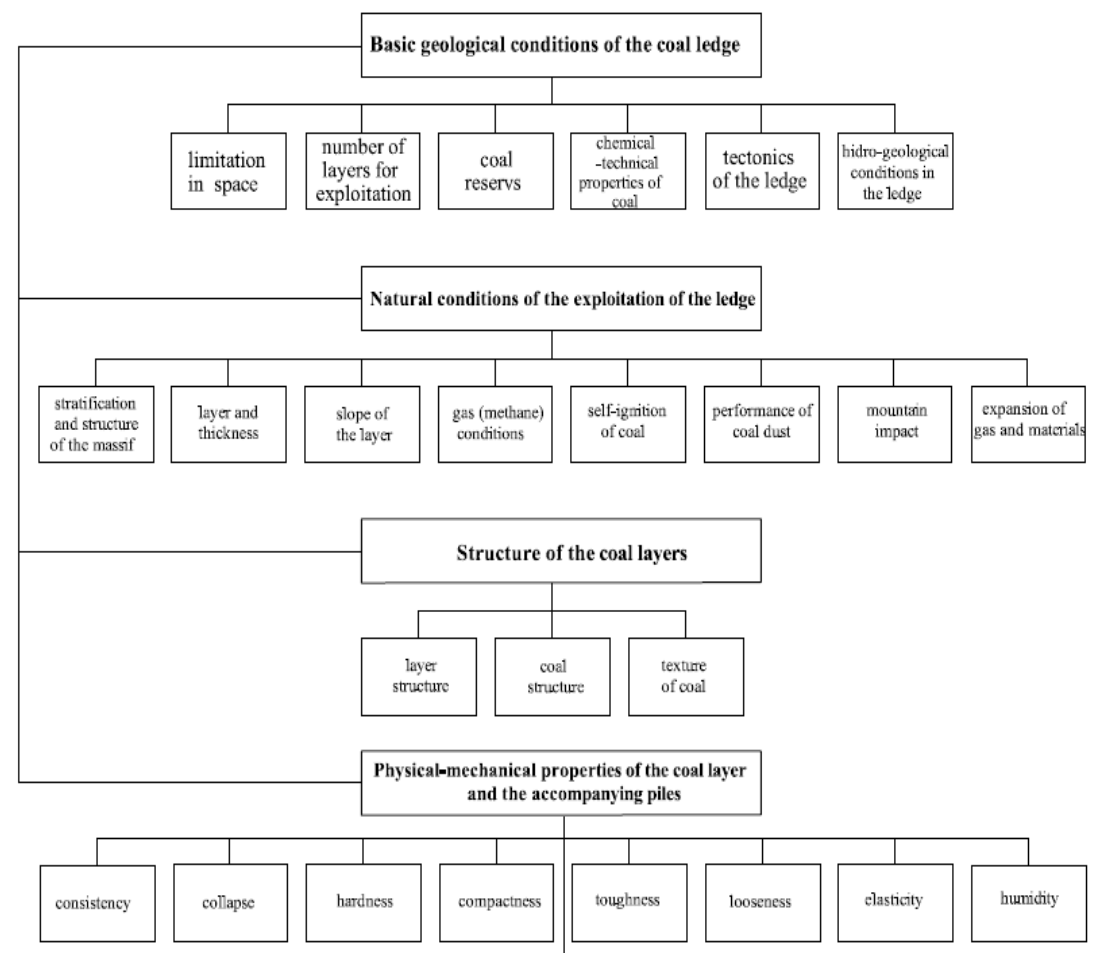

Table 1 Systematization of THE natural-geological conditions influencing the selection of excavation system [10] 
Table 2 Categorization - range impact of natural and geological conditions on selection the excavation systems [10]

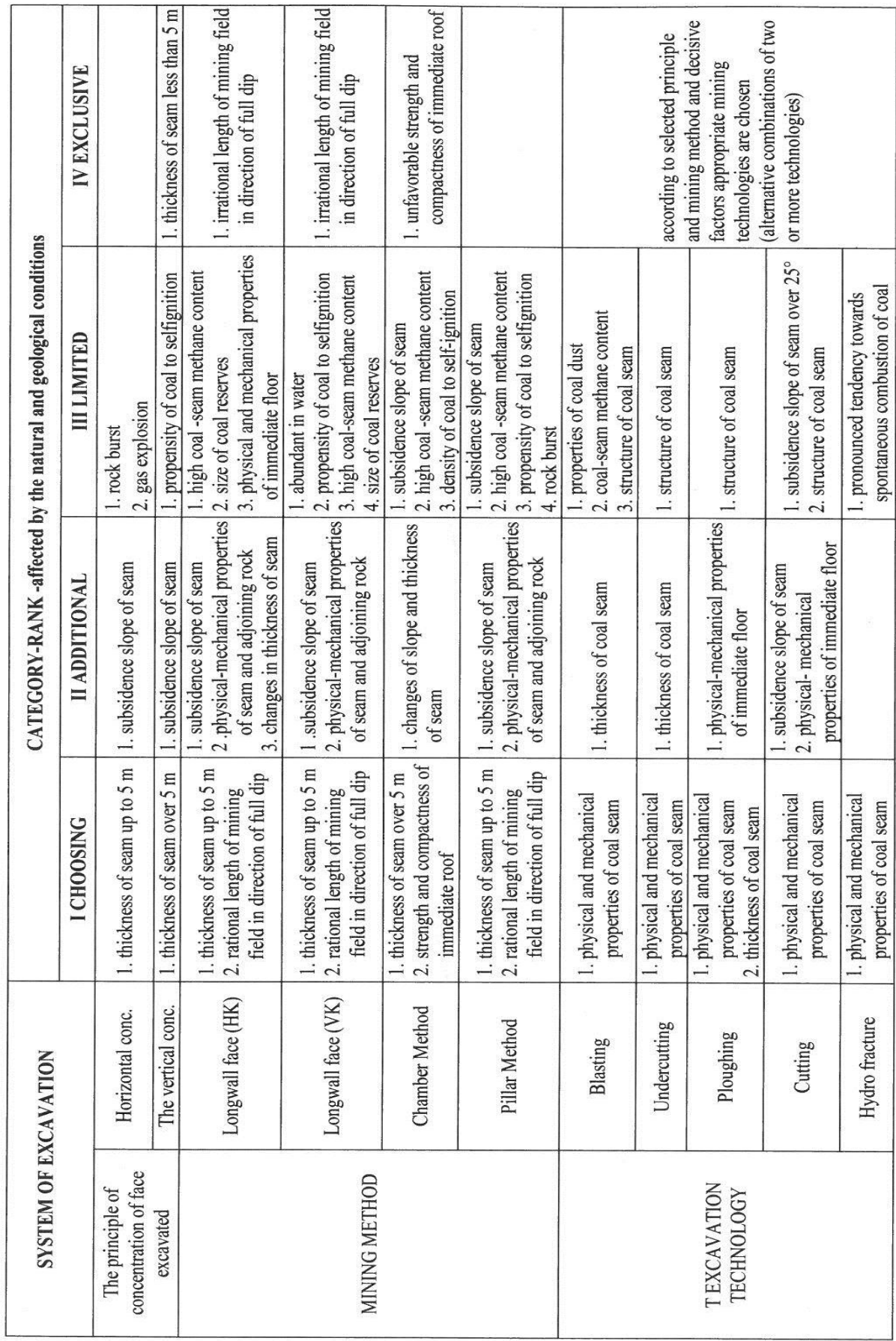




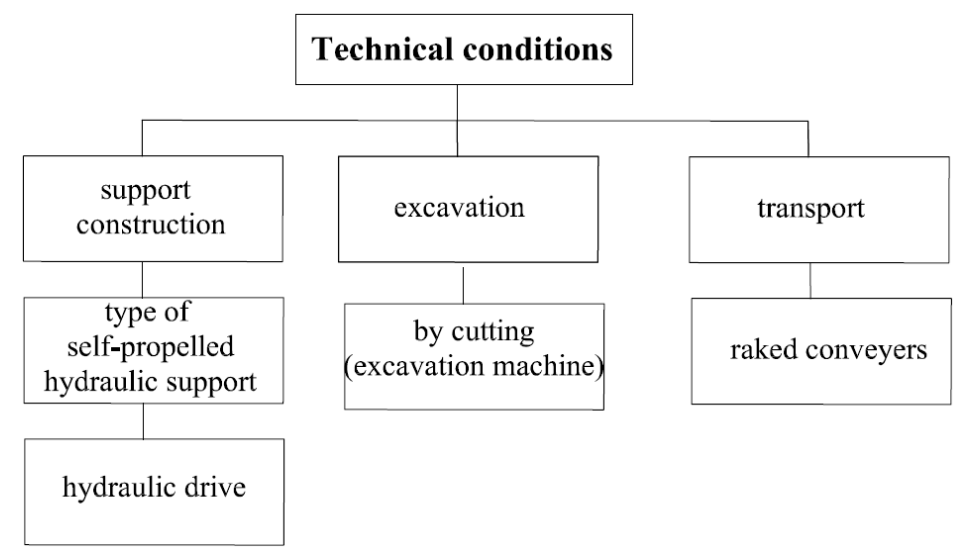

Table 3 Technical conditions for selection the mechanized wide-forehead excavation system based on the principle of horizontal concentration

\section{DESCRIPTION THE NATURAL - GEOLOGICAL CONDITIONS IN THE COAL DEPOSIT "POLJANA"}

The "Poljana" coal deposit belongs to the southern part of the Kostolac coal basin and it is located in a distance of $4 \mathrm{~km}$ from the city of Pozarevac giving it a wellappointed communication links with the consumers. The deposit extends on the relatively narrow belt of the Pozarevac Greda from Pozarevac to the village of Sljivovac in a length of $9 \mathrm{~km}$, and spreads in a direction of the seam fall towards the northwest and sinks under the alluvial of the river Velika Morava. Till now, the maximum researched width of the deposit is $3 \mathrm{~km}$, and the northern border is still open for research [13]

Productive series is represented by the clay-sandy sediments with two coal seams, the lower A which is exploitable and the upper B which has no economic value (unstable thickness, stratified with mullock and poorer quality) [13].

The thickness of the coal seam $\mathrm{A}$ is greatest in the central parts of the deposit and ranges between $4.5 \mathrm{~m}-5.5 \mathrm{~m}$, and the most is $7 \mathrm{~m}$. It is lightly is grown from the south to the north, so the average (weighted) value of the coal seam thickness in various parts ranges from $4.5 \mathrm{~m}$ to $5.06 \mathrm{~m}$. The coal seam has mostly a homogenous structure, rarely stratified with coal clay thickness of $0.2 \mathrm{~m}$, less frequently up to $0.5 \mathrm{~m}$ [13].

Immediate underlying stratum of the main coal seam (A), for the most part, is composed of yellow and gray sands, which may be, to a lesser extent, clayey. Immediate roof via the inter-seam horizon of the seams $\mathrm{A}$ and $\mathrm{B}$, is made of green and blue sandy clay and clay with coal seams and coal clay, or green and blue sand.

Investigations have found that the productive series with coal seams are slightly falling in the direction of the NNW at an angle of about $5^{\circ}$ in general, locally and up to $10^{\circ}$, and yhe bigger inter-seams are not determined in the deposit range, so that the deposit is characterized by a lower tectonic or structural set without tectonic activities. The certified total coal reserves in the deposit are amounted to 62.1 million tons, out of which 58.9 tons are balanced. Based on the analyses of coal quality and ash analysis and related characteristics for coal combustion for coal of this deposit, it is con- 
firmed that it represents a suitable fuel in the domain of energy raw materials and in a wide consumption. The average values of combustion heat are, for lower heat value $10.451 \mathrm{~kJ} / \mathrm{kg}$ and upper heat value $11.960 \mathrm{~kJ} / \mathrm{kg}$ [13].

According to the hydrogeological parameters, the inflow of water into cave rooms, taking into account the static and dynamic reserves, will amount to maximum of $1000 \mathrm{l} / \mathrm{min}$. and that with open works up to $15 \mathrm{~km}$ long. All registered waters in the coal deposit "Poljana" are without pressure, i.e. $\mathrm{t}$ water is at a free level.

The coal deposit "Poljana" is nonmethane at present; there will be no phenomenon of mountain impacts and eruptions, and the coal dust can exhibit hazardous properties under certain conditions, and coal is self-inflammable.

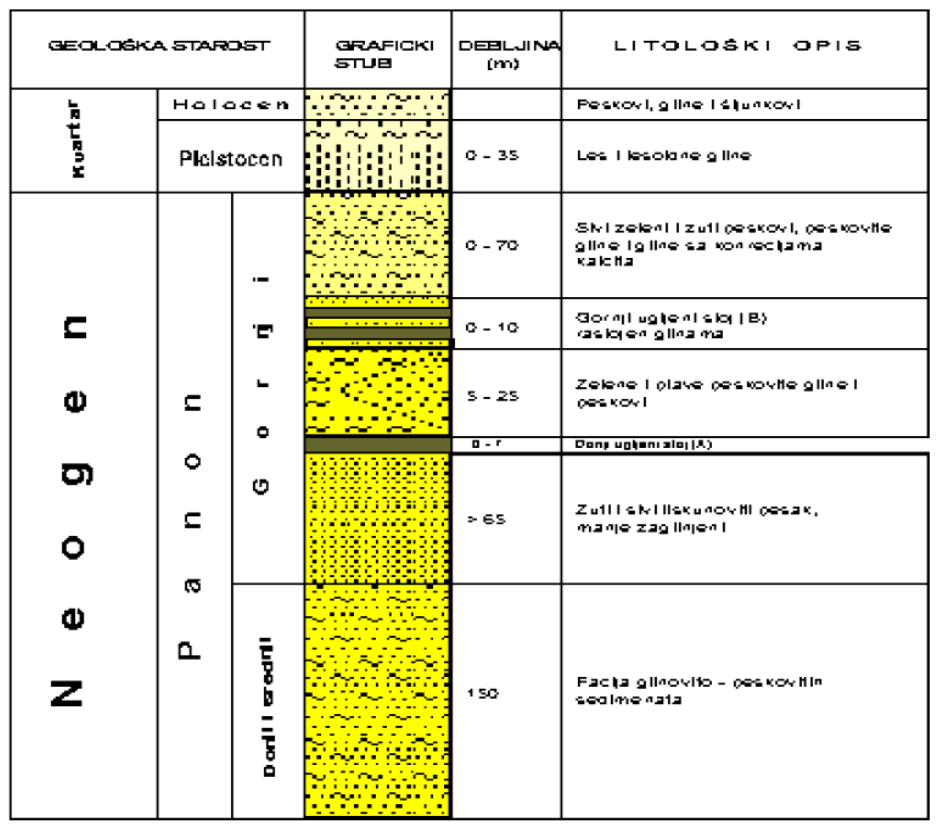

Figure 1 Lithological-stratigraphic pillar of the coal deposit "Poljana" [13]

\section{ANALYSIS OF THE \\ GEOMECHANICAL PARAMETERS}

The subject of the study of geo-mechanical characteristics were the rocks of roof and floor of the coal seams as well as the coal seams themselves. Since the deposit is not mined open or active, the geo-mechanical characteristics are studied through the laboratory-acquired parameters on the physical and mechanical characteristics of these rocks. The laboratory tests were carried out on disturbed and undisturbed samples, depending on a degree of material coherence.

Tests of undisturbed samples of rock masses from the floor were used to determine the grain-size distribution, volumetric mass, water content, angle of internal friction, cohesion, Ateberg limit of consistency (flow limits, boundaries of plasticity, plasticity index and consistency index). The obtained values are shown in Tables 4 and 5 [13]. 
Table 4 Results of testing the disturbed samples of the working environment from the coal deposit "Poljana"

\begin{tabular}{|c|c|c|c|c|c|c|c|c|}
\hline \multirow[b]{2}{*}{$\begin{array}{l}\text { Type } \\
\text { of rock }\end{array}$} & \multicolumn{8}{|c|}{ Parameter name and value } \\
\hline & $\begin{array}{l}\mathrm{W} \\
(\%)\end{array}$ & $\begin{array}{c}\gamma \\
\left(\mathrm{kg} / \mathrm{m}^{3}\right)\end{array}$ & $\begin{array}{c}\varphi \\
\left({ }^{\circ}\right)\end{array}$ & $\begin{array}{c}\mathrm{C} \\
\left(\mathrm{daN} / \mathrm{cm}^{2}\right)\end{array}$ & $\begin{array}{c}\text { Flow } \\
\text { limit, } \\
(\%)\end{array}$ & $\begin{array}{c}\text { Boundaries } \\
\text { of plastici- } \\
\text { ty, }(\%)\end{array}$ & $\begin{array}{c}\text { Plasticity } \\
\text { index }\end{array}$ & $\begin{array}{l}\text { Consistency } \\
\text { index }\end{array}$ \\
\hline Sand III & 9.52 & 1,450 & $31^{\circ}$ & 0.0 & & & & \\
\hline Sand III & 20.52 & - & $30^{\circ} 57^{\prime}$ & 0.0 & & & & \\
\hline Sand III & 23.81 & - & $27^{\circ} 25^{\prime}$ & 0.0 & & & & \\
\hline Clay I & $\begin{array}{l}15.04- \\
23.72\end{array}$ & $\begin{array}{l}1,810- \\
2,070\end{array}$ & $\begin{array}{l}11^{\circ} 30^{\prime}- \\
21^{\circ} 30^{\prime}\end{array}$ & $2.2-5.0$ & $\begin{array}{c}42.58- \\
93.00\end{array}$ & $\begin{array}{c}17.13 \\
-38.48\end{array}$ & $\begin{array}{l}15.43- \\
55.03\end{array}$ & $\begin{array}{c}1.08 \\
-1.63\end{array}$ \\
\hline $\begin{array}{l}\text { Clay } \\
\text { I/II }\end{array}$ & $\begin{array}{l}16.84- \\
28.47\end{array}$ & $\begin{array}{l}1,700- \\
1,810\end{array}$ & $17^{\circ} 40^{\prime}$ & 0.6 & & & & \\
\hline Clay II & $\begin{array}{l}25.53- \\
31.06 \\
\end{array}$ & $\begin{array}{l}1,840- \\
1,900 \\
\end{array}$ & $13^{\circ}$ & $3.0-4.4$ & 61.50 & 31.08 & 30.42 & 1.08 \\
\hline $\begin{array}{l}\text { Sandy } \\
\text { clay II }\end{array}$ & 25.46 & 1,910 & $13^{\circ} 30^{\prime}$ & 2.5 & & & & \\
\hline Loess & $\begin{array}{l}26.83- \\
28.16 \\
\end{array}$ & $\begin{array}{l}1,870- \\
1,950\end{array}$ & $19^{\circ} 58^{\prime}$ & $1.1-2.5$ & $\begin{array}{r}56.50 \\
-63.50 \\
\end{array}$ & $\begin{array}{r}22.78 \\
-23.65 \\
\end{array}$ & $\begin{array}{l}33.72- \\
39.85 \\
\end{array}$ & $\begin{array}{r}0.84 \\
-0.92 \\
\end{array}$ \\
\hline
\end{tabular}

W-humidity; $\gamma$-volumetric mass; $\varphi$-angle of internal friction; C-Cohesion

Table 5 Results of testing the undisturbed samples of the working environment from the coal deposit "Poljana"

\begin{tabular}{|c|c|c|c|c|c|c|c|c|}
\hline \multirow{2}{*}{$\begin{array}{c}\text { Drill } \\
\text { hole/interval }\end{array}$} & \multicolumn{8}{|c|}{ Name and value of parameter } \\
\hline & $\begin{array}{l}W \\
(\%)\end{array}$ & $\begin{array}{c}\gamma_{\mathrm{s}} \\
\left(\mathrm{kg} / \mathrm{m}^{3}\right)\end{array}$ & $\begin{array}{c}\gamma_{1} \\
\left(\mathrm{~kg} / \mathrm{m}^{3}\right)\end{array}$ & $\begin{array}{c}\sigma_{\mathrm{c}} \\
\left(\mathrm{daN} / \mathrm{cm}^{2}\right)\end{array}$ & $\begin{array}{c}\sigma_{\mathbf{i}} \\
\left(\mathrm{daN} / \mathrm{cm}^{2}\right)\end{array}$ & $\begin{array}{c}\mathrm{C} \\
\left(\mathrm{daN} / \mathrm{cm}^{2}\right)\end{array}$ & $\begin{array}{c}\varphi \\
\left({ }^{\circ}\right)\end{array}$ & $\begin{array}{c}E \\
\left(\mathrm{daN} / \mathrm{cm}^{2}\right)\end{array}$ \\
\hline $\begin{array}{c}\text { L-8 } \\
49.9-50.1\end{array}$ & - & - & 1,200 & 49.05 & 5.24 & 9.05 & $52^{\circ} 18^{\prime}$ & - \\
\hline $\begin{array}{c}\text { La-939 } \\
90.0-98.0\end{array}$ & 79.19 & 1,880 & 1,390 & 28.40 & 3.50 & 5.57 & $49^{\circ} 58^{\prime}$ & - \\
\hline $\begin{array}{c}\text { B-759 } \\
76.25-76.65\end{array}$ & 76.08 & & 1,230 & 79.61 & 9.08 & 15.10 & $51^{\circ} 15^{\prime}$ & \\
\hline $77.80-78.20$ & 64.12 & - & 1,340 & 41.15 & 3.13 & 7.40 & $53^{\circ} 15^{\prime}$ & - \\
\hline $78.20-78.60$ & 74.56 & - & 1,220 & 92.08 & 3.10 & 10.39 & $68^{\circ} 18^{\prime}$ & - \\
\hline $\begin{array}{c}\text { Lg-899 } \\
64.00-64.30\end{array}$ & 78.56 & 1,480 & 1,210 & 35.80 & 4.20 & 6.87 & $50^{\circ} 47^{\prime}$ & 1,250 \\
\hline $58.10-58.35$ & 76.00 & 1,570 & 1,230 & 35.10 & 3.10 & 5.97 & $55^{\circ} 18^{\prime}$ & 1,230 \\
\hline $60.07-60.30$ & 89.00 & 1,530 & 1,210 & 23.05 & 3.40 & 4.87 & $46^{\circ} 57^{\prime}$ & 1,175 \\
\hline $\begin{array}{c}\text { La-939 } \\
90.00-90.25\end{array}$ & 87.00 & 1,510 & 1,180 & 119.58 & 50.40 & 33.62 & $17^{\circ} 52^{\prime}$ & 2,240 \\
\hline $92.60-92.90$ & 91.57 & 1,740 & 1,260 & 82.57 & 30.60 & 23.44 & $23^{\circ} 45^{\prime}$ & 1,960 \\
\hline $90.50-93.00$ & 79.17 & 1,880 & 1,390 & 28.40 & 3.50 & 5.57 & $49^{\circ} 58^{\prime}$ & 1,140 \\
\hline Ka-889 & & & & & & & & \\
\hline $51.50-51.80$ & 101.02 & 1,610 & 1,260 & 23.50 & 10.30 & 6.35 & $16^{\circ} 01^{\prime}$ & 1,100 \\
\hline $54.70-54.90$ & 81.48 & 1,650 & 1,270 & 30.46 & 4.16 & 6.24 & $48^{\circ} 15^{\prime}$ & 1,360 \\
\hline $55.80-56.00$ & 69.04 & 1,500 & 1,190 & 79.96 & 7.40 & 13.88 & $54^{\circ} 34^{\prime}$ & 1,790 \\
\hline
\end{tabular}

W-humidity; $\gamma_{\mathrm{s}}$-specific density; $\gamma_{1}$-volumetric mass; $\sigma_{\mathrm{c}}$-compressive strength; $\sigma_{1}$-stretch strength; $\mathrm{C}$-Cohesion; $\varphi$-angle of internal friction; E-modulus of elasticity 
The lithological environments (Figure 1) that can be the subject of mining activity are by strength, mostly incoherent and loose environments in the roof of the main coal seam and partially coherent clayey working environment in the roof sedi- ments. There are several classifications of the working environment $[14,15,16,17]$. According to M.M. Protodacon, based on the hardness, the rocks of the deposit "Poljana" belong to the category from VII-IX (Table 6).

Table 6 Classification of the working environment according to the hardness in the coal deposit "Poljana"

\begin{tabular}{|c|c|c|c|c|c|}
\hline Rock type & Group of rock & Name of the & $\begin{array}{c}\text { Hardness of } \\
\text { the rock }\end{array}$ & Category & $\begin{array}{c}\text { Coefficient } \\
\text { (f) }\end{array}$ \\
\hline Hard rocks & Sedimentary rocks & Coal & $\begin{array}{c}\text { Very } \\
\text { soft }\end{array}$ & VII-a & 0,8 \\
\hline $\begin{array}{c}\text { Connected } \\
\text { (clay) rocks }\end{array}$ & $\begin{array}{c}\text { Un-petrified } \\
\text { compact walls }\end{array}$ & $\begin{array}{c}\text { Sandy clay, } \\
\text { clayey sand }\end{array}$ & $\begin{array}{c}\text { Very } \\
\text { soft }\end{array}$ & VII-a & 0,8 \\
\hline $\begin{array}{c}\text { Unconnected } \\
\text { rocks }\end{array}$ & $\begin{array}{c}\text { Loose, } \\
\text { loess rocks }\end{array}$ & $\begin{array}{c}\text { Loess, } \\
\text { loess clay }\end{array}$ & Loose & IX & 0,6 \\
\hline $\begin{array}{c}\text { Unconnected } \\
\text { rocks }\end{array}$ & $\begin{array}{c}\text { Large-scale, } \\
\text { non-cemented rocks }\end{array}$ & $\begin{array}{c}\text { Gravel, sandy } \\
\text { gravel }\end{array}$ & Loose & IX & 0,5 \\
\hline
\end{tabular}

Clays and partly sandy clays are located in a wide interval below the loess and loess clays, all the way to the A-horizon, and partly occur in the floor of A-horizon (the thickness is up to $0.6 \mathrm{~m}$ ). Otherwise, in the roof as well as in the floor, they are replaced by sand and clay sand. They make many heterogeneous physical - mechanical characteristics that are conditioned by their composition, both mineralogical and granulometrical. The clays between A and B horizon have the weakest physical-mechanical characteristics, since their cohesion is the smallest (around $0.60 \mathrm{daN} / \mathrm{cm}^{2}$ ), and the angle of internal friction is about $17^{\circ}$. The sandy clays and clays immediately in the floor and roof of A-horizon have the smallest resistance to shear because their internal friction angle is $13^{\circ}$, while cohesion is larger and ranges from 2.5 to $4.4 \mathrm{daN} / \mathrm{cm}^{2}$. These clays are the most important because they are located next to the coal itself so that the underground rooms will often pass through such an environment that is prone to swelling.

Sand and partly clay sand extends over the entire interval of loess and loess clay in seams with clay and sandy clay to the floor of the A-horizon, and everywhere appearing in the floor of coal or along with thin seams of dark grey clay. No other tests were carried out since it was not possible to take the undisturbed samples by the exploration drilling, except determination the grain-size distribution in the laboratory. Based on the experience data, the following values, volumetric mass and angles of internal friction can be adopted: $\gamma=1800$ to $1900 \mathrm{~kg} / \mathrm{m}^{3}$; $\varphi=30-40^{\circ}$, while cohesion for pure sand is c $=0$, and it increases to $0.5 \mathrm{daN} / \mathrm{cm}^{2}$ for clay sand. These sands are dry and anhydrous in the conditions of the coal deposit "Poljana", which was ascertained by the exploration drilling. They are suitable as an environment for mining works, provided that support is done immediately after excavation. Stability of walls of underground rooms is higher in clay sand than in sand $[18,19]$. Based on the penetration experiments, carried out in drills, the permitted loading of the floor sands is about $5 \mathrm{daN} / \mathrm{cm}^{2}$. Problems will arise in load transferring from the roof seams to the floor of underground rooms, because the carrying 
capacity of these sands is not sufficient, so the protective coal boards will have to be left in the floor of the mining rooms and facilities.

Coal, i.e. coal seam, is mostly homogeneous in its lithological composition; it is less abrupt with coal clay, but it is cut by cracks and fissures that extend approximately parallel to a direction of providing the coal seam with a sub-verticular decline. The crack size varies from 0 to $2 \mathrm{~mm}$. Coatings of a fine crystalline pyrite were observed on the walls of cracks. Coal is a wooden structured and brittle. Being in the air, coal quickly dries up and becomes friable and breaks into smaller pieces. Based on described natural conditions, which, in this stage of research, are proved in the coal deposit "Poljana", it is possible to predict the method of development and potential coal exploitation in this deposit.

\section{METHODOLOGICAL PROCEDURE OF SELECTION THE TYPE AND CONSTRUCTION THE SELF-PROPELLED HYDRAULIC SUPPORT}

Based on the analysis of geo-mechanical parameters, it is concluded that one of the modern methods of excavation of the wideforehead type can be used in the deposit.

Selection of the method was, to a considerable extent, influenced by the following reasons:

$>$ Adverse thickness of 0-6 m (4.7 m) of coal seam eliminates the effective application of mechanized wideforehead with vertical excavation concentration;

Application of the vertical excavation concentration would not give the designed effects due to the small thickness of coal in the upper coal seam because it would much faster aloud penetration of the mullock as a specific heavier material than coal. According to the known deposit and experience, this would significantly, if not completely, impair the efficiency of the system [20,21,22];

$>$ Blending of coal with the mullock in the process of vertical excavation concentration would require the separation (cleaning) of the raw coal, or otherwise the quality of commercial product would be permanently and significantly reduced. In the case of using the coal cleaning, there would be significant increases in the total production costs.

With a high degree of accuracy, it can be established that, in the conditions of the coal deposit "Poljana", the horizontal concentration system of the excavation will bring a higher percentage of utilization of the affected coal reserves than the vertical concentration. The following relation also shows this:

- Horizontal concentration: 4.2: $4.7=89.4 \%$ (due to leaving the plate of coal);

- Vertical concentration: $89.4 \% \times(2.5+(0.6 \times 1.7))=66.9 \%$, or without leaving a plate of coal $(2.5+(0.6 \times 2.2))=81.2 \%$.

The vertical excavation system significantly increases the potential risk of endogenous cave fires. Especially when considering the relative proximity of the terrain surface (the average depth of the coal seam is $86 \mathrm{~m}$ ), with which the excavation could, via cracks and fissures, establish the communication of air.

In excavation by the horizontal concentration system, the terrain surface is evenly shrugging and causes minor damage to the surface of the terrain.

By detailed analysis, the impacts of natural geological conditions in a particular deposit can be concluded that the use of a mechanized wide-forehead method of excavation by the principle of horizontal concentration, by the technology of obtaining by cutting, is rational. 
In the concrete case of the coal deposit "Poljana", based on the analysis, it was concluded that the self-propelled hydraulic support must satisfy the following construc-tive conditions:

1. It is necessary to achieve a complete protection of the working space while ensuring the necessary working confrontation;

2. To transmit as little pressure on the floor as possible, which depends of the surface area of the support and system and direction of transmission the pressure force from the roof;

3. To have a complete functionality and compliance with the excavation machine and coal transportation transporter;

4. The total resistance of dynamic support elements without mechanical gearbox should not be less than $3,200 \mathrm{kN}$ per section of the selfpropelled hydraulic support;

5. The hydraulic cylinder on the shielded timber (board) shall be capable of withstanding a mechanical part of at least $150 \mathrm{kN}$;

6. To have an automatic elastic indulgence of the support in the event of increased load on support;

7. It should provide the hydraulic range of adjustment of digging height from $2.0 \mathrm{~m}$ to $4.5 \mathrm{~m}$;

8. Tensile force of the self-propelled hydraulic support should be at least 2,400 kN per section;
9. To have cylinders for withdrawal of section and suppressing the frontal transporter with a power of $450 \mathrm{kN}$ or $250 \mathrm{kN}$ per cylinder;

10. The step of moving the sections should be max. $800 \mathrm{~mm}$ per one move.

Taking into account these requirements and geo-mechanical, i.e. physical - mechanical properties of the working environment, and which should be taken with the reserve until the new targeted tests are carried out, the type of shield support has been chosen. This type of self-propelled hydraulic support, even at the most disadvantageous position of the support, transmits the most direct and minimum pressure on the excavation floor and adapts well to the vertical, horizontal and eccentric loads on the support; it well protects the working area of the forehead and provides the mechanization for all working operations and functional accommodation, and connection with the other equipment on a wide-forehead, also providing the conditions of work comfort.

Based on the presented, methodological procedure of selection the type and selection the self-propelled hydraulic support, applied to the mechanized wide-forehead excavation, based on the principle of horizontal concentration, consists of the following phases (Table 7).

Table 7 Methodological procedure of the self-propelled hydraulic support type

\begin{tabular}{|l|}
\hline $\begin{array}{l}\text { 1. Systematization of the available data of natural-geological conditions for concrete deposit, } \\
\text { with an assessment the need for additional research. }\end{array}$ \\
$\downarrow$ \\
\hline $\begin{array}{l}\text { 2. Selection of parameters (methods and technologies) of excavation system with mecha- } \\
\text { nized wide-forehead with definition the necessary equipment. }\end{array}$ \\
$\downarrow$ \\
\hline 3. Systematization of technical conditions for equipment of a particular excavation system. \\
$\qquad$ \\
\hline $\begin{array}{l}\text { 4. A detailed analysis of the physical and mechanical properties of coal and asso-ciated } \\
\text { rocks, selection the self-propelled hydraulic support type, consideration the joint action of } \\
\text { rock massif and self-propelled hydraulic support with calculations of the strain in the floor } \\
\text { and roof, and defining the requirements for structural characteristics. }\end{array}$ \\
\hline
\end{tabular}




\section{CONCLUSION}

This work processes the methodological procedure of selection the type and construction of self-propelled hydraulic support on a mechanized wide-forehead excavation, based on the principle of horizontal concentration for specific conditions. Based on the defined procedure, the same methodology can be applied to the other coal deposits in which the mentioned method of excavation is applied.

A further step, that is the continuation of research, is a new dedicated investigation of the physical and mechanical properties of coal seams and accompanying sediments in the geo-mechanics laboratory in order to build, based on the obtained results, the construction requirements for self-propelled hydraulic support and make an adequate selection from a wide range of various manufacturers.

\section{REFERENCES}

[1] Ivković, M., 1999. The Impact of Natural Geological Conditions on the Selection and Sizing the System of Mining the Coal Seams of High Thickness; Monograph; Dunavpreving Belgrade, Belgrade (in Serbian)

[2] H.P. Kang, J. Lin, M.J. Fan. 2015. Investigation on Support Pattern of a Coal Mine Roadway Within Soft Rocks - A Case Study. International Journal of Coal Geology 140, 31-40

[3] F. Gao, D. Stead, J. Coggan, 2014. Evaluation of Coal Longwall Caving Characteristics Using An Innovative UDEC Trigon Approach. Computers and Geotechnics 55, 448-460

[4] Ljubojev, M., Popović, R. 2006. Fundamentals of Geomechanics; Monograph; RTB - Bor, Copper Institute Bor, Indok Center, Bor (in Serbian)
[5] Popović, R., Ljubojev, M. 2007 Principles of Problem Solving in Geomechanics; Monograph; RTB Bor, Copper Institute Bor, Indok Center, Bor (in Serbian)

[6] H. Alehossein, B.A.Poulsen, 2010. Stress Analysis of Longwall Top Coal Caving. International Journal of Rock Mechanics and Mining Science 47 (1), 30-41

[7] G.X.XieJ, C.Chang, K.Yang, 2009 Investigations into Stress Shell Characteristics of Surrounding Rock in Fully Mechanized Top-Coal Caving Face. International Journal of Rock Mechanics and Mining Science 46 (1), 172-181

[8] Ivković, M., 1999. Methodology for Selection the SHP for Excavation the Brown Coal Seams by the Method Of Wide Foreheads According to the Principle of Vertical Concentration; V Symposium with the International Participation in the Field of Mining Industry, Faculty of Mining and Geology - Belgrade, Belgrade (in Serbian)

[9] A. Vakili, B.K. Hebblewhite, 2010. A New Cavability Assessment Criterion for Longwall Top Coal Caving. International Journal of Rock Mechanics and Mining Science 47 (8), 1317-1329

[10] Ivković, M., 1997. Rational Systems of Underground Excavation the Brown Coal Seams of High Thickness in the Complex Exploitation Conditions, Doctoral Dissertation, Faculty of Mining and Geology - Belgrade, Belgrade (in Serbian)

[11] Suljkanović, M., 1998. Analysis the Methods of Forecasting the Synergies of Pit Massif and the MHP in a Wide Forehead Excavation of Coal Seams; 
Journal ZE No.2/98, Zenica Mines, Zenica (in Bosnian)

[12] Čokorilo V., 1993. Mechanized Hydraulic Support; Monograph; Faculty of Mining and Geology Belgrade, Belgrade (in Serbian)

[13] Investment Program of Opening and Exploitation the Lignite Mine "Poljana", Mining Part, Books 1 and 2; 1983. Ugaljprojekt - Belgrade, Belgrade (in Serbian)

[14] S. E. Phillipson. 2008. Texture, Mineralogy, and Rock Strength in Horizontal Stress-Related Coal Mine Roof Falls. International Journal of Coal Geology 75 (3), 175-184

[15] C.A. Ozturk, E. Nasuf. 2013. Strength Classification of Rock Material Based on Textural Properties. Tunelling and Undergound Space Tehnology 37, 4554

[16] S.H. Hoseinie, M. Ataei, M. Osanloo. 2009. A New Classification System for Evaluating Rock Penetrability. International Journal of Rock Mechanics and Mining Science 46 (8), 1329-1340

[17] H. Munoz, A. Taheri, E. Chanda. 2016. Rock Cutting Characteristics on Soft-to-Hard Rocks Under Different Cutter Inclinations. International Journal of Rock Mechanics and Mining Science 87, 85-89
[18] Jelušič, P. Žlender, B. 2013. Soil-Nail Wall Stability Analysis Using ANFIS. Acta Geotechnica Slovenica 10 (1), 61-73

[19] F. Gao, D. Stead, H. Kang. 2014. Simulation of Roof Shear Failure in Coal Mine Roadways Using an Innovative UDEC Trigon Approach. Computers and Geotechnics 61, 33-41

[20] Y. Liu, F, Zhou, X, Geng, L, Chang,J, Kang,G,Cui,S,Zhang. 2017. A Prediction Model and Numerical Simulation of the Location of the Longwall Face During the Highest Possible Failure Period of Gob Gas Ventholes. Journal of Natural Gas Science and Engineering 37, 178-191

[21] Y. Fujii, Y. Ishijima, G. Deguchi. 1997. Prediction of Coal Face Rock Bursts and Micro Seismicity in Deep Longwall Coal Mining. International Journal of Rock Mechanics and Mining Science 34 (1), 85-96

[22] A. Majdi, F. P. Hassani, M.Y. Nasir. 2012. Prediction of the Height of Destressed Zone above the Mined Panel Roof in Longwall Coal Mining. International Journal of Coal Geology 98, 62-72. 